\title{
The Relationship between Multiple Intelligences and Participation Rate in Extracurricular Activities of Students from a Catholic Education Institution
}

\author{
John Mark R. Asio ${ }^{1 * ~(D)}$, Christopher D. C. Francisco ${ }^{2}$ (D) Alvin V. Nuqui $^{3}$ (D)
}

${ }^{1}$ Gordon College, PHILIPPINES

${ }^{2}$ Marcelo H. Del Pilar National High School, PHILIPPINES

${ }^{3}$ DepEd SDO-Bulacan, PHILIPPINES

*Corresponding Author: asio.johnmark@gmail.com

Citation: Asio, J. M. R., Francisco, C. D. C., \& Nuqui, A. V. (2021). The Relationship between Multiple Intelligences and Participation Rate in Extracurricular Activities of Students from a Catholic Education Institution. International Journal of Professional Development, Learners and Learning, 3(1), ep2107. https://doi.org/10.30935/ijpdll/10956

\begin{abstract}
Multiple intelligences and extracurricular activities are two variables that may affect a student's academic and nonacademic performance in school. This study aimed at describing and finding the relationship between multiple intelligences and participation rates in extracurricular activities of students from a Catholic educational institution. The study also used a descriptive-correlational design. For the respondents, the study randomly selected a sample of 200 students studying within the academic year of 2017-2018 from a Catholic educational institution. For the instrument, this study adapted the Multiple Intelligence Survey developed by Chislett and Chapman (2006) and Extracurricular Activities Survey by Kelley (2012). The study analyzed and treated statistically the collected data using rank and Spearman Rho with the help of SPSS 20. The findings revealed that visual intelligence emerged as the top-ranked multiple intelligences. Dance/ sports club emerged as the top extracurricular activities took part by most of the students. Also, there was no statistical evidence of the relationship between the multiple intelligences and participation rate to extracurricular activities of the students. Based on the result, the researchers provided pertinent recommendations for teachers, students, and the institution.
\end{abstract}

Keywords: multiple intelligences, participation rate, extracurricular activities, correlation study

Received: 23 Dec. $2020 \bullet$ Accepted: 20 Feb. 2021

\section{INTRODUCTION}

Most scholars on Multiple Intelligences claim that MI-based instructions have a great significant effect on students learning, on how students learn inside and outside the classroom. Bas (2016) has found out that Multiple Intelligence theory-based education has a significant effect on the students' academic achievement. Jimenez (2020) stated that improving the students' problem-solving ability remains a challenge to teachers and students. Abdi et al. (2013) showed that students instructed through Teaching Strategy based on Multiple Intelligences achieved a higher score than the ones with traditional instruction. Safein's (2012) study showed the Multiple Intelligences based program had a significant effect on improving the subjects' listening and speaking skills.

There are so many literatures today that focused on the applying multiple intelligences in various ways. For example, a study described the effects of multiple intelligence-based reading tasks on both EFL male and female learners' reading comprehension (Modirkhamene \& Azhiri 2012). From the study of Otieza (2013), they showed that innovative intelligences-based reading tasks grants chances to discover, value, and enhance the talents of learners. This is for a learner's better tackling of reading comprehension shortcomings. The author also revealed a relationship between multiple and language learning strategies. According to Ermis and Imamoglu (2013), doing sports has a positive effect on verbal, interpersonal, and kinesthetic intelligence. Thus, we encourage students to be in sports.

In another study by Akyol (2018), the author determined whether drama education causes any difference in the multiple intelligences of children. Because of the study, there was no significant difference between the children in the experimental and control groups in terms of their pretest and posttest mean scores. From the paper of Abdulkarim and Al Jadiry (2012), the team showed that there was no significant difference in acquiring physical concepts because of the cooperative learning group division based on multiple intelligences theory and previous achievement. Still, in most cases, cooperative learning has a significant effect on the students, those who are not well-equipped in acquiring concepts.

Multiple intelligences also influence the academic achievements of students in an overall sense. From the study of Bicer (2017), studentcentered learning methods have an overall positive and high-level effect 
on the academic success of students. The company of Ahvan et al., (2016) studied the relationship between multiple intelligences and academic performance achievement of students and found a positive relationship. Multiple regression analyses showed that visual-spatial, interpersonal and verbal-linguistic intelligence predicts academic performance achievement. In some sex-concern concerning Multiple Intelligence-based Instruction, the researchers have found out that there are blind spots among authors like Obianuju et al. (2015), Punia and Jyoti (2016).

From the perspective of Kasmahsari (2015), it revealed that educators recognize the many paths to understanding, and students learn best when they can engage in activities that involve their strengths. In a Southeast Asian country, teachers' daily lesson planning integrates the multiple intelligence elements and approaches. Naeini (2015) also discovered that integrating multiple intelligence theory can contribute to enhancing of learners' listening comprehension. Also, the effect is even more significant if the teachers practice the integration of all intelligence rather than the most developed ones. Finally, Bas and Beyhan (2010) exposed that the students educated by multiple intelligences supported project-based learning methods are more successful. In addition, these students have a higher motivation level than the students who are educated by the traditional instructional methods.

This particular paper focuses on the idea to prove whether the students' multiple intelligences affect the participation rate of students to extracurricular activities of the school. The focus inspired the researchers since an advocate of multiple intelligences; Devlin (2010) claimed that there was no significance between students' learning style and the participation rate in extracurricular activities.

The purpose of this study includes the describe the level of multiple intelligence of the students of a private higher education institution, to determine the level of the participation rate in extracurricular activities of the students, and to analyze the relationship between students' multiple intelligences and the participation rate in extracurricular activities of the institution.

This study hopes to contribute to the ever-growing ideas and concepts of multiple intelligences and how it affects students. Also, the researchers hope to help teachers, educators, and the like in realizing the innate capacity of students and their hunger for learning. Considering this minute detail could help both students and teachers build a solid foundation of the teaching-learning process.

\section{METHODOLOGY}

The researchers used a descriptive-correlation design of the study with the survey as the primary instrument for data gathering. The aim of the study is to discover the relationship between multiple intelligence and participation in extracurricular activities, such a correlation type applies to this current study.

To achieve the study's aim, the researchers took a sample of 200 students from the senior high school department of a private higher education institution in the academic year 2017-2018. The researchers used a simple random sampling technique in establishing the sample for this study.

For the instrument, the researchers adapted the "Multiple Intelligence Test" developed by Chislett and Chapman (2006) based on
Howard Gardner's Multiple Intelligences Model. This test is a standardized test and available online. The "Extracurricular Activities Survey" established by Kelley (2012) is an investigatory study which examined the participation in extracurricular activities of students. Prior to the actual administration of the survey, a pool of experts examined the said instrument for reliability. They consisted a seasoned researcher-publisher, a university professor (with experience in research publication), a senior high school teacher and a school guidance counselor. The researchers considered their comments and suggestions to improve the instrument. Furthermore, a pilot survey of the instrument commenced to a group of students who were not part of the survey to find out any misunderstood terms and concepts.

After gathering and tabulating the data using Microsoft Excel, the proponents used Spearman Rho to extract the correlation between the two variables of this study. The researchers used the Statistical Package for Social Science (SPSS) 20 in the correlation's computation using Spearman Rho as a statistical method.

\section{RESULTS}

This study aimed to analyze the relationship between multiple intelligences and the participation rate of students in extracurricular activities. This study revealed the results shown in Figure 1.

Figure 1 showed the result of multiple intelligence lists of the respondents of the study. As seen, the lowest-ranked intelligence rated by the respondents was the linguistic-intelligence which falls on the 9th order. The next lowest raked intelligence was logical, which falls on the 8th position. Existential intelligence was in 7th place. The 6th positioned intelligence was kinesthetic, followed by the naturalist intelligence on the 5th position. For the 4th place, the interpersonal intelligence came in, followed by musical intelligence in 3rd place. The highest places intelligence was visual, followed by intrapersonal intelligence in second place.

Figure 2 displayed the result of the extracurricular activities survey to the respondents. As observed, the figure showed that Altar-servers' club and Augustino Chronicles club is the lowest-ranked clubs in the 8th and 7th position. The Arts Club (6th place) and the Nature-lovers' club (5th place) followed next. In the 4th position were the Peer Facilitators' club/Usher and Usherettes' club followed by the Choir club that ranked 3rd. The Dance/Sports Club took the 1st place and Theatre club the second place.

Table 1 showed the Multiple Intelligences with its corresponding extracurricular activities/clubs. We set the equivalence of each extracurricular activity to the multiple intelligences according to the club and organizations' job descriptions (the Students' Development Services Archives provided the information). First, linguistic/verbal intelligence corresponds to the Augustino Chronicles. Second, logical/mathematical intelligence has no corresponding extracurricular activity. Third, musical intelligence corresponds to choir club. Fourth, spatial/visual intelligence corresponds to the Arts club. Fifth, the bodily/kinesthetic club corresponds to sports varsity club and to dance club. Sixth, we see intrapersonal intelligence within Altar Servers Club. Seventh, we see interpersonal intelligence in peer facilitators' club and in usher and usherettes club. Eighth, naturalistic intelligence corresponds to nature lovers' club. Last, we see existential intelligence with theatre club. 


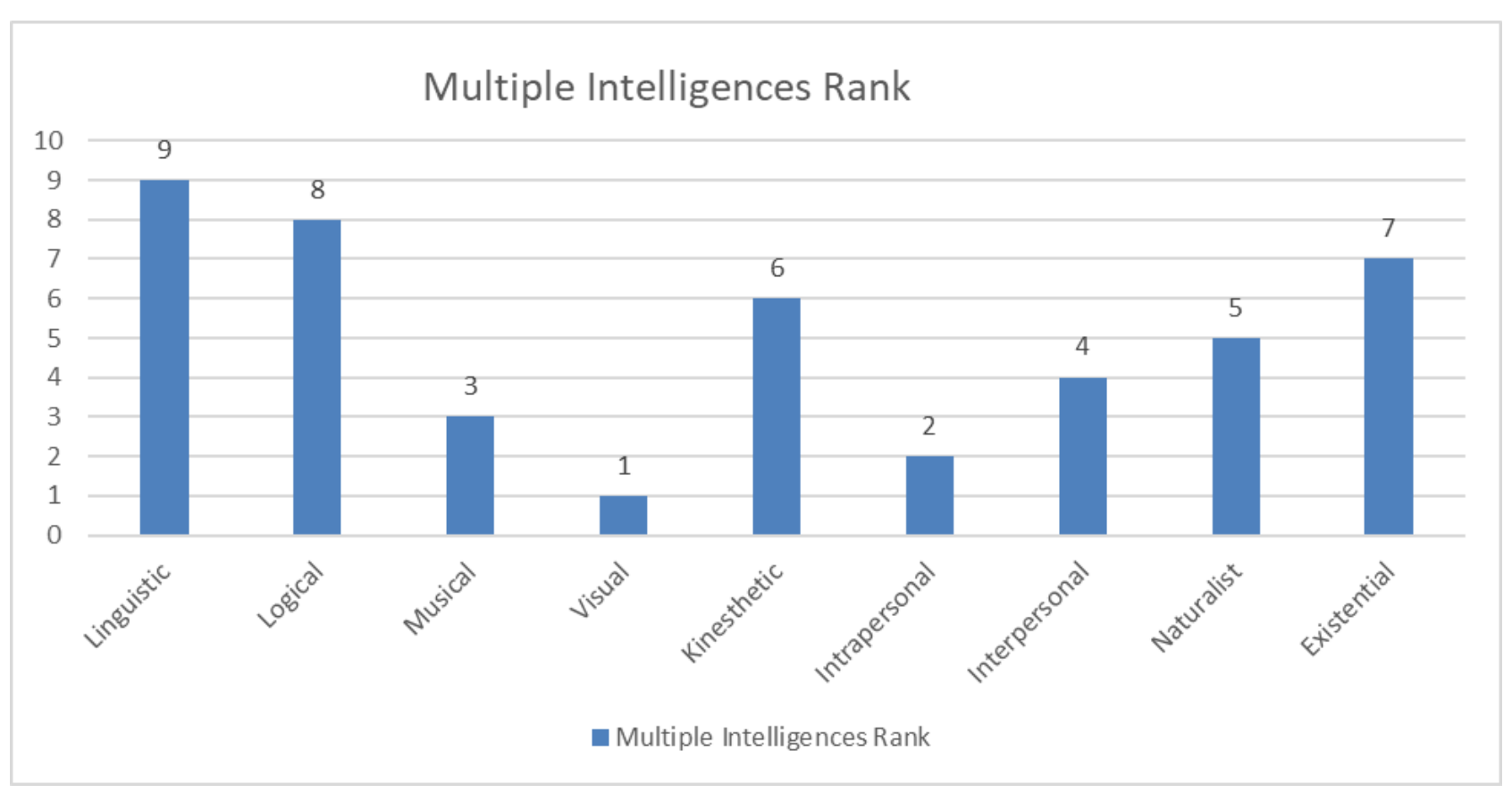

Figure 1. Multiple Intelligence Inventory by Gardner (2007)

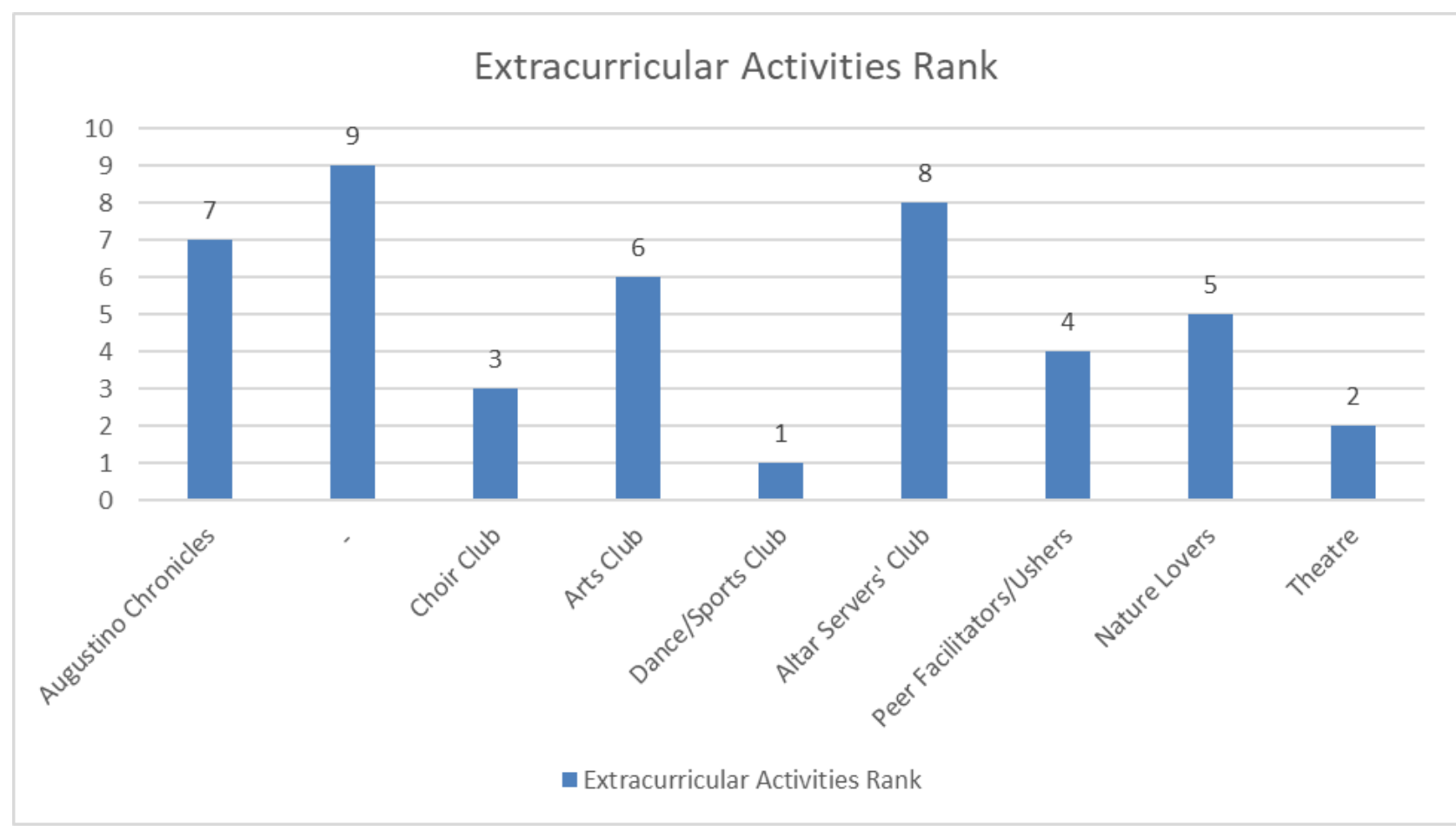

Figure 2. Extracurricular Activities Survey by Kelley (2012)

Table 1. Multiple Intelligence and their Corresponding Extracurricular Activities

\begin{tabular}{ccc}
\hline No. & MULTIPLE INTELLIGENCES (MI) & EXTRACURRICULAR ACTIVITIES (ECA) \\
\hline 1 & Linguistic/Verbal & Augustino Chronicles \\
\hline 2 & Logical/Mathematical & No Club Available \\
\hline 3 & Musical & Choir Club \\
\hline 4 & Spatial/Visual & Arts Club \\
\hline 5 & Bodily/Kinesthetic & Sports Varsity Club / Dance Club \\
\hline 6 & Intrapersonal & Altar Servers' Club \\
\hline 7 & Interpersonal & Peer Facilitators' Club / Ushers and Usherettes \\
\hline 8 & Naturalist & Nature Lovers' Club \\
\hline 9 & Existential & Theatre Club
\end{tabular}




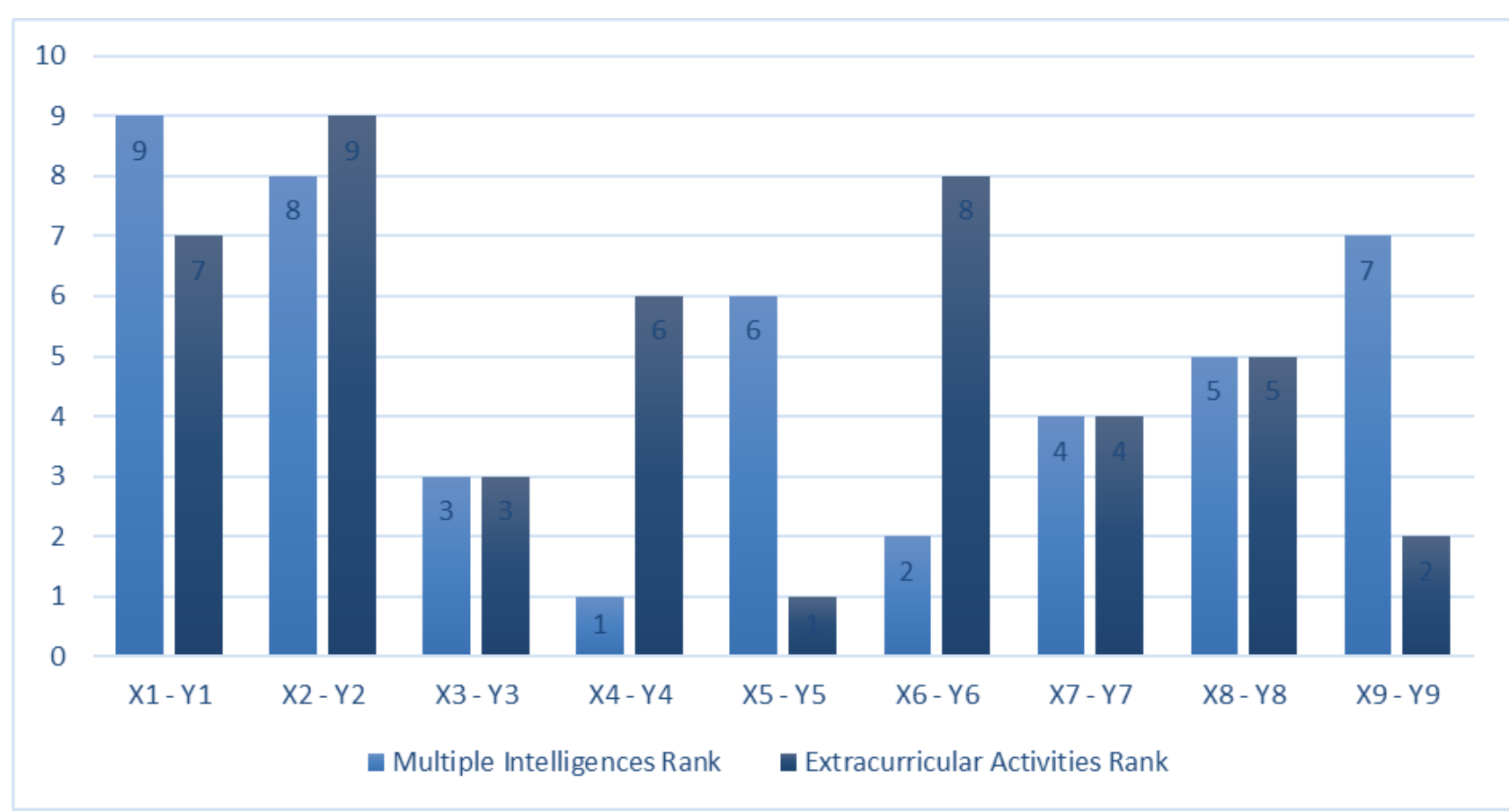

Figure 3. Relationship between Multiple Intelligences and Extracurricular Activities Participation Rate

Table 2. Computation of Correlation Coefficient Using Spearman Rho

\begin{tabular}{|c|c|c|c|c|}
\hline & & & Rank of $X$ & Rank Y \\
\hline \multirow{6}{*}{ Spearman's rho } & \multirow{3}{*}{ Rank of X } & Correlation Coefficient & 1.00 & .033 \\
\hline & & Sig. (2-tailed) & & .932 \\
\hline & & $\mathrm{N}$ & & 9 \\
\hline & \multirow{3}{*}{ Rank of $Y$} & Correlation Coefficient & .033 & 1.00 \\
\hline & & Sig. (2-tailed) & .932 & \\
\hline & & $\mathrm{N}$ & 9 & \\
\hline
\end{tabular}

${ }^{*} p>.05$

Figure 3 showed the relation between multiple intelligences versus extracurricular activities. The Augustino Chronicles as conceived to be as 9th in participation rate rank while the Linguistic-intelligence falls under 7 th in rank. Both Choir Club as well as being 8th. Both $\mathrm{X} 3$ and $\mathrm{Y} 3$ are 3 rd. The $\mathrm{X} 4$ is 1 st while $\mathrm{Y} 4$ is 6 th. The $\mathrm{X} 6$ is 2 nd while $\mathrm{Y} 6$ is 7 th. The $\mathrm{X} 7$ is 4 while the $\mathrm{Y} 7$ is also 4 th. Both $\mathrm{X} 8$ and $\mathrm{Y} 8$ are the same as the 5th. The $\mathrm{X} 9$ is 7 th while the $Y 9$ is 2 nd (Please refer to Figure 1 and Figure 2).

Table 2 revealed the computation of the correlation coefficient between multiple intelligence and extracurricular activities using Spearman Rho. The X-variable was the multiple intelligences. The Yvariable was the extracurricular activities. As seen, there was no significant relationship between the two variables. This is because the Spearman's rho correlation coefficient result of .033. It has a corresponding probability value of .932 . The $p$-value is greater than the Alpha significance level of .05 . This showed further that the multiple intelligence rank differs from extracurricular activities rank. Therefore, the multiple intelligences of a student are not one of the key factors that influence the participation rate of the students to extracurricular activities in the school.

\section{DISCUSSION}

This study described the multiple intelligences and extracurricular activities participation of students from a private higher education institution. It also analyzed the relationship between multiple intelligences and extracurricular activities participation of students.

The result of the study is interesting. In multiple intelligences, the linguistics intelligence ranked the lowest and the visual intelligence ranked on top. The reason seems to be that majority of students are visual learners thus, visual intelligence top the list. Therefore, teachers need to capitalize on such opportunity, so more students appreciate the lessons at hand by using technology-based learning. In a parallel idea, Shabiralyan (2015) shared that majority of teachers and students had affirmative perceptions of the use of visual aids and other learning material that would appease the students in visual learning. The next intelligence on the list was intrapersonal. We deduct that technologybased learning affected intrapersonal intelligent individuals. Suhana (2017) posited that ICT usage of children leads to self-isolation from social life and a lack of emotional management. The third most exhibited intelligence is musical. Music aids students through learning just like Kusnierek (2016) stated that teaching with the use of music highly motivates students. Sebastian (2020) concluded that using music is effective in improving a student's performance. For the fourth, most exhibited intelligence is interpersonal. The increase of gadget use and exposure to social media, students nowadays lack social skills and other related life skills. However, Slof et al. (2016) suggested that the interpersonal skills of students predict the degree to which computersupported collaborative learning has influenced students' achievement. Next came the naturalistic intelligence which ranked 5th in position. Students live in a world where diversity exists and plenty of issues and 
concerns to address such as health concerns, environment protection, economic growth, and many more. A study by Adisendjaja et al. (2019) concluded that field trip influences students' naturalistic intelligence. The last four remaining positions belonged to kinesthetic intelligence, existential intelligence, and logical intelligence which placed 6th, 7th, 8th, and 9th. With these final four in mind, the results seemed low, and these areas need improvement. In terms of existential intelligence, Francisco (2016) in a philosophical paper stated that there should be a primacy of faith to that of reason. Concerning the logical intelligence, a study recommended that problem-based learning might improve the level of critical thinking skills of students (Lapuz \& Fulgencio, 2020).

In terms of the participation rate of the students in extracurricular activities, the study revealed a $93.5 \%$ percent of the total 200 respondents or 186 students who take part in any of the activities that the institution provides. The remaining $6.5 \%$ responded have other things in mind than to join extracurricular activities. To attain the researchers' aim, participation in clubs was likewise ranked in the order. The students choose which club activities to engage themselves in. The researchers ranked the students' participation in club activities based on students' preference. The different clubs were: (1) Dance/Sports Club, (2) Theatre Club, (3) Choir, (4) Peer Facilitator's Club, (5) Nature Lovers Club, (6) Arts Club, with (7) Augustino Chronicles and (8) Altar Servers' Club as the least preferred clubs and organizations.

In this particular study, the researchers emphasize the nonacademic clubs as organizations that are independent in nature. There is no direct influence from other colleges/ departments. The membership is open to all bonafide students regardless of the college/department. These organization's activities are more of the extracurricular types. They provide opportunities for the enrichment of skills and attitudes of the students. This in turn contributes to the total welfare of the individual, creating a holistic member of the society. Larson et al. (2006) reported the profiles of youth in terms of developmental experiences across different organized activities. Mahoney et al. (2003) on the other hand, associated extracurricular activities with high educational status. Besides, Lewis, (2004) argued that participation in extracurricular activities enhances student's selfesteem and self-efficacy which motivates them to work to achieve academic goals.

According to Craft (2012), students that participate in extracurricular activities have a slightly higher grade point average. Extracurricular activities also provide an avenue for strengthening the lessons learned and offer an opportunity to apply academic skills in a real-world context. Hence, the extracurricular activity is a significant constituent of a student's experience in school. It encourages the holistic growth of each student. That is why, teachers should lead students in the best extracurricular activities that best suit their interests and intelligence.

\section{CONCLUSION}

Based on the result and findings of the study, the researchers concluded that in terms of multiple intelligences, visual intelligence emerged on top of the survey. However, linguistic intelligence is at the bottom of the ranking. On the other hand, for the participation rate of extracurricular activities of students, the dance/ sports club came up on top of the survey. Yet, the altar servers were the least favored extracurricular activities for students. In the context of the relationship between the two variables, there was no statistical evidence that supports the idea that multiple intelligences have a significant relationship to the students' participation rate to extracurricular activities.

\section{RECOMMENDATIONS}

This study aimed to describe the multiple intelligences and participation rates of extracurricular activities of students. At the same time, analyze the relationship between the two variables. Based on the result of the study, the researchers provide the following recommendations:

1. Teachers in the participating institution should consider enriching and enhancing other intelligence like those at the bottom of the ranking.

2. Encourage teachers to integrate other multiple intelligences in their lessons and activities for students.

3. For the institution, since there were only eight extracurricular activities listed and considered for this study, the researchers suggest providing more options or other extracurricular activities for students to choose from.

4. The institution should empower the student affairs office for extracurricular activities of students.

5. The students may consider determining their own intelligences as it could boost their self-confidence as an individual and a student.

6. Students may opt to join extra-curricular activities since this could help develop their talents and skills especially in competitions in and outside the school.

7. The institution may give contingent rewards to encourage students to participate in various competitions that would show up the good image of the institution that they represent.

Author contributions: All authors were involved in concept, design, collection of data, interpretation, writing, and critically revising the article. All authors approve final version of the article.

Funding: The authors received no financial support for the research and/or authorship of this article.

Declaration of in terest: Authors declare no competing interest.

Data availability: Data generated or analysed during this study are available from the authors on request.

\section{REFERENCES}

Abdi, A. Laei, S., \& Ahmadyan, H. (2013). The effects of teaching strategy based on multiple intelligences on students' academic achievement in science course. Universal Journal of Educational Research, 1(4), 281-284. https://doi.org/10.13189/ujer.2013.010401

Abdulkarim, R., \& Al Jadiry, A. (2012). The effect of using cooperative learning and multiple intelligences theory on physical concepts acquisition. British Journal of Arts \& Social Sciences, 10 (11), 137-152. https://www.academia.edu/20875459/The_Effect_of_Using_Coo perative_Learning_and_Multiple_Intelligences_Theory_on_Physi cal_Concepts_Acquisition 
Adisendjaja, Y. H., Abdi, M. K. K., Amprasto, A., \& Fardhani, I. (2019). The influence of field trip on junior high school students' naturalistic intelligence and problem-solving skills in ecosystem subject. Jurnal Pendidikan IPA Indonesia, 8(3), 339-346. https://doi.org/10.15294/jpii.v8i3.19532

Ahvan, Y. R., Zailanipour, H., Jamri, M., \& Mahmoodi, F. (2016). The correlation between Gardner's multiple intelligences and problemsolving styles and their role in the academic performance achievement of high school students. European Online Journal of Natural and Social Sciences, 5(1), 32-39. https://europeanscience.com/eojnss/article/view/2921

Akyol, A. K. (2018). Examination of the effect of drama education on multiple intelligence areas of children. Early Chid Development and Care, 188(2), 157-167. https://doi.org/10.1080/03004430.2016. 1207635

Bas, G. (2016). The effect of multiple intelligences theory-based education on academic achievement: A meta-analytic review. Educational Sciences: Theory \& Practice, 16(6), 1833-1864. https://doi.org/10.12738/estp.2016.6.0015

Bas, G., \& Beyhan, O. (2010). Effects of multiple intelligences supported project-based learning on students' achievement levels and attitudes towards English lesson. International Electronic Journal of Elementary Education, 2(3), 365-386. https://files.eric.ed.gov/ fulltext/EJ1052017.pdf

Bicer, N. (2017). The influence of student-centered methods in Turkish language instruction on academic success: A meta-analysis study. Universal Journal of Educational Research, 5(4), 687-697. https://doi.org/10.13189/ujer.2017050419

Chislett, V., \& Chapman, A. (2006). Multiple intelligences test - based on Howard Gardners' MI theory. https://www.businessballs.com/free pdfmaterials/free_multiple_intelligences_test_manual_version.pdf

Craft, S. W. (2012). The impact of extracurricular activities on student achievement at the high school level [Doctoral dissertation, University of Southern Mississippi]. Dissertations, 543. https://aquila.usm.edu/dissertations/543

Devlin, B. M. (2010). Effects of students' multiple intelligences on participation rate of course components in a blended secondary family and consumer sciences course [Master's thesis, Iowa State University] Graduate Theses and Dissertation. 11286. https://lib.dr.iastate.edu /etd/11286

Ermis, E., \& Imamoglu, O. (2013). The effects of doing sports on the multiple intelligences of university students. International Journal of Academic Research, 5(5B), 174-179. https://doi.org/10.7813/20754124.2013/5-5/B.26

Francisco, C. DC. (2016). Amo ut sciam: The relation of knowledge and love in the light of St. Bonaventure's exemplarism. International Multidisciplinary Scientific Conference on the Dialogue between Sciences $\&$ Arts, Religion \& Education, 9-21. https://doi.org/10.26520/ mcdsare.2017.1.9-21

Jimenez, E. C. (2020). Problem solving ability of first year high school students in Mathematics as affected by cognitive development levels and teaching strategies. Instabright, e-Gazette, 1(3), 1-22. https://doi.org/10.2139/ssrn.3530765
Kasmahsari, B. H. K. (2015). The effects of multiple intelligences approaches in learning English grammar in the classroom [Master's thesis, Universiti Malaysia Sarawak]. http://ir.unimas.my/id/eprint/ 12602

Kelly, D. (2012). An investigatory study into the relationship between extracurricular activities and stress/worry in exam years [Bachelor's thesis, DBS School of Arts]. https://esource.dbs.ie/bitstream/han dle/10788/419/ba_kelly_d_2012.pdf?sequence=1\&isAllowed=y

Kusnierek, A. (2016). The role of music and songs in teaching English vocabulary to students. World Scientific News, 43(1), 1-55. http://www.worldscientificnews.com/wp-content/uploads/2015/ 10/WSN-431-2016-1-55.pdf

Lapuz, A. M. E., \& Fulgencio, M. N. (2020). Improving critical thinking skills of secondary school students using problem-based learning. International Journal of Academic Multidisciplinary Research, 4(1), 1-7. https://ssrn.com/abstract=3543211

Larson, R. W., Hansen, D. M., \& Moneta, G. (2006). Differing profiles of developmental experiences across types of organized youth activities. Developmental Psychology, 42(5), 849-863. https://doi.org/10.1037/0012-1649.42.5.849

Lewis, C. P. (2004). The relation between extracurricular activities with academic and social competencies in school age children: A meta-analysis (Doctoral dissertation, Texas A \& M University). http://hdl.handle.net/1969.1/2710

Mahoney, J. L., Cairns, B. D., \& Farmer, T. W. (2003). Promoting interpersonal competence and educational success through extracurricular activity participation. Journal of Educational Psychology, 95(2), 409-418. https://doi.org/10.1037/00220663.95.2.409

Modirkhamene, S., \& Azhiri, M. H. B. (2012). The effect of multiple intelligences-based reading tasks on EFL learners' reading comprehension. Theory and Practice in Language Studies, 2(5), 10131021. https://doi.org/10.4304/tpls.2.5.1013-1021.

Naeini, M. B. (2015). Comparing the effects of two facets of multiple intelligences theory on developing EFL learners' listening. Advances in Language and Literary Studies, 6(4), 62-71. https://doi.org/10.7575/aiac.alls.v.6n.4p.62

Obianuju, O. S., Akuezuilo, E. O., \& Okoli, J. N. (2015). Effect of multiple intelligence-based instructional technique (MIBIT) on students' interest in the learning of difficult Biology concepts. IOSR Journal of Research \& Method in Education, 5(3), 1-9. https://doi.org/10.9790/7388-05340109

Otieza, S. U. (2013). The multiple intelligences theory and language learning strategies: relation and the effect of instruction. Universidad Publica de Navarra. https://pdfs.semanticscholar.org/ f2a0/63ff27254df7a4aa87b2f89154fd1a6dc344.pdf

Punia, V., \& Jyoti, J. (2016). Effect of gender on underlying factors of multiple intelligence among school going children. International Journal of Science Technology and Management, 5(8), 778-786. https://doi.org/10.21275/v5i4.NOV162487

Safein, A. A. M. (2012). The effect on multiple intelligences theory-based instruction on developing listening and speaking skills of prospective teachers of English [Master's thesis, Cairo University]. http://e repository.cu.edu.eg/index.php/cutheses/article/view/3922/3855 
Sebastian, M. F. DC. (2020). Using songs as springboard to teaching poetry and narratives towards improved comprehension. International Journal of Academic and Applied Research, 4(6), 72-78. https://files.eric.ed.gov/fulltext/ED606278.pdf

Shabiralyani, G., Hasan, K. S., Hamad, N., \& Iqbal, N. (2015). Impact of visual aids in enhancing the learning process case research: District Dera Ghazi Khan. Journal of Education and Practice, 6(19), 226-234. https://files.eric.ed.gov/fulltext/EJ1079541.pdf
Slof B., Nijdam, D., \& Janssen, J. (2016). DO interpersonal skills and interpersonal perceptions predict student learning in CSCLenvironment? Computers $\&$ Education, 97, 49-60. https://doi.org/10.1016/j.compedu.2016.02.012

Suhana, M. (2017). Influence of gadget usage on children's socialemotional development. Advances in Social Science, Education and Humanities Research, 169, 224-227. https://doi.org/10.2991/icece17.2018 .58 